\title{
Respon Pertumbuhan dan Hasil Tanaman Hanjeli (Coix lacryma-jobi L.) terhadap Jarak Tanam dan Pupuk Pelengkap Cair
}

\author{
Ruminta*, Yuyun Yuwariah dan Nalendia Sabrina \\ Program Studi Agroteknologi Fakultas Pertanian Universitas Padjadjaran \\ Jl. Raya Bandung-Sumedang KM 21 Jatinangor Jawa Barat 45363 \\ *Alamat Korespondensi: ruminta@unpad.ac.id
}

\begin{abstract}
Resposse of Growth and Yields of Jobs Tears to Row Spacing and Liquid Complement Fertilizer

Job's tears (Coix laeryama-jobi L.) are a functional food crop in West Java Indonesia. It is rich of nutritions when used as food and also rich of essential chemicals when used as herbal. It can grow on marginal ecosystem, tolerance to water stress's environment. However, Job's tears are low in grain production. The problem could be overcome by treatment of row spacing and liquid complement fertilizers to increase the plants growth and yields. This study used three levels of row spacing $(50 \times 50 \mathrm{~cm}, 75 \times 50 \mathrm{~cm}$, and $100 \times 50 \mathrm{~cm}$ ) and three levels of liquid complement fertilizers $(2 \mathrm{ml} / \mathrm{l}, 4 \mathrm{ml} / \mathrm{l}$, and $6 \mathrm{ml} / \mathrm{l})$ to examine the growth and yields of jobs tears. The experiment used Randomized Block Design (RBD) consisted of nine treatments and three replications. The experiment was conducted at Sukasari Sumedang West Java. Growth and yield indicators such as leaf area index, percentage of huskering and harvesting index were observed. The results showed that the treatments of row spacing and liquid complement fertilizer had significantly affected the leaf area index, percentage of huskering and Job's tears harvesting index. The combination of plant spacing at $50 \times 50 \mathrm{~cm}$ with the concentration of liquid complement fertilizer at level $2 \mathrm{ml} / 1$ showed the best effect to the jobs tears yield. It resulted the weight of seeds of $4.77 \mathrm{~kg} / \mathrm{plot}$ and the weight of seed was 5.96 tons/ha. This indicated that the row spacing and liquid complement fertilizer had significantly affecting the Job's tears yield.
\end{abstract}

Keywords: Job's tears, Row spacing, Liquid complement fertilizer, Growth, Yields

\begin{abstract}
ABSTRAK
Tanaman hanjeli merupakan tanaman pangan fungsional di Jawa Barat Indonesia. Tanaman hanjeli sangat kaya nutrisi sebagai sumber makanan dan kaya bahan kimia penting sebagai tanaman herbal. Tanaman tersebut dapat tumbuh pada lahan marjinal dan toleran terhadap cekaman air, namun demikian hasilnya masih rendah. Penelitian ini bertujuan untuk mengetahui pengaruh perlakuan jarak tanam dan pemberian pupuk pelengkap cair terhadap peningkatan pertumbuhan dan hasil tanaman hanjeli. Penelitian ini menggunakan tiga level jarak tanam $(50 \times 50 \mathrm{~cm}, 75 \times 50 \mathrm{~cm}$, dan 100x50 cm) dan tiga level konsentrasi pupuk pelengkap cair (PPC) $(2$ $\mathrm{ml} / \mathrm{l}, 4 \mathrm{ml} / \mathrm{l}$, dan $6 \mathrm{ml} / \mathrm{l}$ ) sebagai perlakuan. Percobaan di lapangan menggunakan Rancangan Acak Kelompok (RAK) yang terdiri dari 9 perlakuan dan tiga kali ulangan yang dilaksanakan di Sukasari Sumedang Jawa Barat. Data yang diamati adalah komponen pertumbuhan dan hasil tanam hanjeli. Hasil penelitian menunjukkan bahwa kombinasi jarak tanam dengan aplikasi pupuk pelengkap cair memberikan pengaruh terhadap indeks luas daun, rendemen pecah kulit, dan indeks panen. Kombinasi jarak tanam 50 x 50 dengan konsentrasi PPC $2 \mathrm{ml} / 1$ memberikan pengaruh terbaik terhadap hasil tanaman hanjeli. Perlakuan tersebut menghasilkan bobot biji per petak sebesar 4,77 kg per petak dan bobot biji per hektar sebesar 5,96 ton per hektar. Dari hasil penelitian ini dapat disimpulkan bahwa jarak tanam dan pupuk pelengkap cair memberikan pengaruh yang baik terhadap hasil tanaman hanjeli.
\end{abstract}

Kata Kunci : Hanjeli, Jarak tanam, Pupuk pelengkap cair, Pertumbuhan, Hasil 


\section{PENDAHULUAN}

Dalam memenuhi kebutuhan pangan dibutuhkan dilakukan program intensifikasi, ekstensifikasi, dan diversifikasi pangan. Program diversifikasi pangan adalah penganekaragaman bahan makanan pangan selain beras sebagai sumber karbohidrat yang memiliki kandungan yang sama atau lebih baik dibandingkan nasi. Hanjeli merupakan tanaman pangan yang dapat menjadi alternatif dalam pemenuhan pangan di Indonesia. Hanjeli (Coix lacryma-jobi) merupakan tanaman sumber karbohidrat dan juga herbal yang dikenal di Indonesia dengan beberapa nama lain seperti hajeli, jelai, jali, japen, atau jeten. Sementara di negara lain hanjeli disebut Job's tears (Australia), adlay (Filipina), Sila (Fiji) dan mayuen (China). Tanaman hanjeli berasal dari Asia Tenggara dan diduga berasal dari Indonesia. Di Indonesia tanaman hanjeli sudah mulai dikembangkan pada beberapa daerah khususnya di daerah Jawa Barat yakni, Ciamis, Tanjung Sari, Punclut, Cirebon, Sukabumi dan Garut. Tanaman hanjeli juga berpotensi untuk dikembangkan sebagai tanaman adaptif terhadap perubahan iklim karena tahan terhadap kekeringan ataupun tergenang air (Ruminta \& Nurmala, 2016). Tanaman hanjeli memiliki kandungan gizi yang baik untuk tubuh manusia, hanjeli mengandung protein, lemak, dan vitamin B1 lebih tinggi bila dibandingkan tanaman serealia lainnya. Demikian pula kandungan $\mathrm{Ca}$ pada tanaman hanjeli lebih tinggi dibandingkan beras, jagung, serta sorghum (Grubben \& Partohardjono, 1996; Wicaksono dkk., 2006). Selain dapat dimanfaatkan sebagai sumber pangan, hanjeli juga dapat berperan sebagai obat herbal dan bahan kerajinan. Dengan daya adaptasinya yang tinggi terhadap cekaman kekeringan maupun kebanjiran, potensi tanaman hanjeli untuk dikembangkan di Indonesia sangatlah tinggi. Potensi tersebut masih belum dimanfaatkan oleh masyarakat Indonesia sendiri. Hal ini terjadi karena ketidaktahuan petani terhadap manfaat serta teknik budidaya hanjeli itu sendiri.

Teknik budidaya yang baik sangat mendukung keberhasilan penanaman dan hasil panen. Pemupukan yang dilakukan melalui tanah tidak selalu dapat memenuhi kecukupan hara bagi tanaman, karena adanya pencucian hara, volatilisasi dan denitrifikasi yang menyebabkan efisisensi pemupukan menjadi rendah. Permasalahan tersebut dapat ditanggulangi dengan cara memberikan hara melalui pemupukan yang diberikan melalui daun. Menurut Barbieri et al., (2000) pupuk daun merupakan pupuk yang dapat menanggulangi kekurangan hara yang telah diberikan melalui tanah. Penyerapan hara yang diberikan melalui pupuk daun berjalan lebih cepat dibanding pupuk yang diberikan lewat akar. Menurut Mulyono (2003), pupuk daun mampu mempercepat proses fisiologi tanaman dan agar lebih efektif. Hasil penelitian Rahmayani (2006) menunjukkan bahwa penambahan pupuk pelengkap cair (PPC) memberikan efek yang lebih baik terhadap pertumbuhan, produksi, serta serapan hara $\mathrm{N}, \mathrm{P}, \mathrm{K}$ pada tanaman padi sawah IR64 dibandingkan dengan perlakuan standar (250 kg Urea/ha, $150 \mathrm{~kg}$ SP-36/ha, dan $100 \mathrm{~kg} \mathrm{KCl} / \mathrm{ha}$ ), maupun perlakuan kontrol (tanpa pupuk). Pemberian pupuk pelengkap cair berpengaruh sangat nyata terhadap tinggi tanaman, jumlah anakan total per rumpun, jumlah malai per rumpun, jumlah gabah isi per malai, bobot gabah kering per petak, bobot gabah kering per rumpun, bobot 1000 butir gabah, panjang malai, jumlah gabah hampa per malai dan bobot gabah kering per rumpun pada tanaman padi varietas Conde (Supriyanto dkk,, 2010). PPC merupakan pupuk pelengkap yang di berikan pada bagian daun tanaman yang menggunakan sistem penetrasi sehingga terjadi penyerapan langsung oleh tanaman melalui daun yang diserap melalui stomata.

Pemberian unsur hara yang tepat apabila tidak diiringi dengan jarak tanam yang tepat akan mengakibatkan adanya kompetisi antar tanaman terhadap unsur hara yang diberikan, sehingga akan mempengaruhi pertumbuhan dan hasil tanaman hanjeli yang dapat menyebabkan penurunan dan mengakibatkan penambahan unsur hara menjadi tidak optimal (Pederson and Laurer, 2003). Pengaturan jarak tanam dilakukan sebagai upaya memanipulasi tanaman agar kanopi serta akar tanaman dapat memanfaatkan faktor lingkungan secara optimal dan mengurangi persaingan penggunaan cahaya, air, dan ruang tumbuh. Pada umumnya makin panjang umur tanaman maka tanaman akan semakin tinggi dan memerlukan tempat yang lebih luas. Jarak tanam pada tanaman hanjeli tergantung jenis varietasnya, namun pada umumnya jarak tanam yang digunakan untuk tanaman hanjeli adalah $40 \times 60 \mathrm{~cm}, 60 \times 30 \mathrm{~cm}$, dan $60 \times 60 \mathrm{~cm}$ (Nurmala \& Irawan, 2007). Jarak tanam yang lebih lebar memudahkan untuk penyebaran sistem perakaran dan berpengaruh terhadap efisiensi penggunaan tempat dan pemberian pupuk. Pengaturan jarak tanam dapat menghindari terjadinya tumpang tindih diantara tajuk tanaman, memberikan ruang bagi perkembangan akar dan 
tajuk tanaman dan meningkatkan efisiensi penggunaan benih. Sistem jarak tanam mempengaruhi cahaya, $\mathrm{CO}_{2}$, angin dan unsur hara yang diperoleh tanaman sehingga akan berpengaruh pada proses fotosintesis yang pada akhirnya memberikan pengaruh yang berbeda pada parameter pertumbuhan dan produksi tanaman. Jarak tanam yang lebih sempit mampu meningkatkan produksi per luas lahan dan jumlah biji namun menurunkan bobot biji (Ruminta dkk., 2016; Irwan dkk., 2017; Putra, 2011).

Dengan adanya pengaturan jarak tanam dan pemberian PPC dengan konsentrasi tepat akan memberikan pengaruh terhadap pertumbuhan dan hasil tanaman. Penggunaan konsentrasi PPC dan jarak tanam yang optimum akan menghasilkan pertumbuhan dan hasil tanaman yang lebih baik. Informasi mengenai jarak tanam serta penggunaan konsentrasi pupuk pelengkap cair yang tepat serta kemungkinan adanya pengaruh terhadap pertumbuhan dan hasil tanaman hanjeli masih belum diketahui, sehingga perlu dilakukan penelitian mengenai hal tersebut. Penelitian ini bertujuan untuk mengetahui jarak tanam dan konsentrasi PPC yang memberikan pengaruh terbaik pada pertumbuhan dan hasil tanaman hanjeli ( $C$. lacryma-jobi L.). Hasil penelitian ini diharapkan dapat memberikan informasi tentang jarak tanam dan konsentrasi PPC yang memberikan pengaruh terbaik pada pertumbuhan dan hasil tanaman hanjeli (C. lacryma-jobi L.). Hasil penelitian ini juga diharapkan dapat menjadi bahan informasi terhadap perkembangan ilmu pertanian dan petani ataupun pengusaha di bidang tanaman hanjeli terutama dalam jarak tanam dan konsentrasi PPC yang terbaik untuk pertanaman hanjeli.

\section{BAHAN DAN METODE}

Percobaan dilaksanakan di Desa Sindangsari, Kecamatan Sukasari, Kabupaten Sumedang dengan ketinggian 800 mdpl. Bahan tanaman yang digunakan pada percobaan ini adalah benih hanjeli Pulut aksesi 37 (benih dari koleksi Laboratorium Produksi dan Pemuliaan Tanaman Fakultas Pertanian Universitas Padjadjaran) dan pupuk pelengkap cair (PPC).

Percobaan menggunakan Rancangan Acak Kelompok (RAK) yang terdiri dari 3 perlakuan jarak tanam $(50 \times 50 \mathrm{~cm}, 75 \times 50 \mathrm{~cm}$, dan $100 \times 50 \mathrm{~cm})$ dan 3 perlakuan PPC ( $2 \mathrm{ml} / \mathrm{l}, 4 \mathrm{ml} / \mathrm{l}$, dan $6 \mathrm{ml} / \mathrm{l}$ air $)$ sehingga terdapat sembilan kombinasi perlakuan yang diulang sebanyak tiga. Adapun sembilan kombinasi perlakuan tersebut adalah sebagai berikut : A. Jarak tanam $50 \times 50 \mathrm{~cm}+$ PPC $2 \mathrm{ml} / \mathrm{l}$; B. Jarak tanam $50 \times 50 \mathrm{~cm}+$ PPC $4 \mathrm{ml} / \mathrm{l}$; C. Jarak tanam 50 x $50 \mathrm{~cm}+$ PPC $6 \mathrm{ml} / \mathrm{l}$; D. Jarak tanam $75 \times 50 \mathrm{~cm}+$ PCC $2 \mathrm{ml} / \mathrm{l}$; E. Jarak tanam 75 x $50 \mathrm{~cm}+$ PPC $4 \mathrm{ml} / \mathrm{l}$; F. Jarak tanam $75 \times 50 \mathrm{~cm}+$ PPC $6 \mathrm{ml} / \mathrm{l}$; G. Jarak tanam $100 \times 50 \mathrm{~cm}+$ PPC $2 \mathrm{ml} / \mathrm{l} ; \mathrm{H}$. Jarak tanam 100 x $50 \mathrm{~cm}+$ PPC $4 \mathrm{ml} / \mathrm{l}$; dan I. Jarak tanam 100 x 50 $\mathrm{cm}+$ PPC $6 \mathrm{ml} / \mathrm{l}$. Petak percobaan berukuran $4 \times 2$ $\mathrm{m}$. Jarak antar petak 0,5 $\mathrm{m}$ dan jarak antar ulangan 1 m. Tanaman sampel untuk setiap petak berjumlah 4 tanaman per petak yang diambil secara acak dari seluruh tanaman kecuali baris tanaman paling luar atau border. Pemeliharaan, pemupukan anorganik, pengairan, pengendalian organisme pengganggu tanaman dibuat seragam unutk semua perlakuan. Data hasil percobaan dianalisis menggunakan software SPSS 19. Uji F dan uji Scott-Knott pada taraf 5\% dilakukan untuk menguji perbedaan antar rata-rata perlakuan. Pengamatan pada tanaman sampel dilakukan dengan mengukur berbagai komponen pertumbuhan dan hasil. Komponen pertumbuhan yang diamati antara lain tinggi tanaman, jumlah daun, jumlah anakan, jumlah srisip, indeks luas daun dan nisbah pupus akar. Sementara komponen hasil dan hasil panen yang diamati adalah jumlah malai, jumlah biji, kekerasan biji, bobot biji, rendemen biji pecah kulit dan indeks panen.

\section{HASIL DAN PEMBAHASAN}

\section{Pertumbuhan Hanjeli}

Tinggi tanaman merupakan indikator pertumbuhan yang digunakan untuk mengukur perlakuan yang diterapkan. Hasil analisis ragam menunjukkan bahwa perlakuan kombinasi jarak tanam dengan PPC tidak memberikan pengaruh terhadap tinggi tanaman (Tabel 1). Tinggi tanaman hanjeli pada percobaan ini dapat mencapai $255 \mathrm{~cm}$, hal ini menunjukkan bahwa pertumbuhan cukup baik dibandingkan dengan deskripsi hanjeli aksesi 37 yang hanya mencapai 169,64 cm. Hasil analisis tanah menunjukkan bahwa kandungan nitrogen pada tanah tergolong rendah, dengan diberikannya pupuk urea $(45 \% \quad \mathrm{~N})$ sebanyak $350 \mathrm{~kg} / \mathrm{ha}$ dapat menghasilkan tanaman yang pertumbuhannya optimal. Fase pertumbuhan tanaman di pengaruhi oleh beberapa faktor yaitu ketersediaan unsur hara di dalam tanah khususnya kandungan nitrogen yang merupakan bagian pokok dalam penyusunan protein, asam nukleat, klorofil, dan senyawa organik 
lain. Menurut Humpreys (1978), unsur nitrogen yang tersedia akan dimanfaatkan untuk pertumbuhan vegetatif terlebih dahulu yaitu penambahan tinggi dan penambahan jumlah daun. Sehingga pertumbuhan tinggi tanaman pada setiap perlakuan akan relatif sama. Unsur $P$ juga berperan dalam proses pembelahan sel membentuk organ tanaman, sehingga berperan dalam penambahan tinggi tanaman (Puspadewi dkk., 2016). Selain unsur hara, faktor yang mempengaruhi adalah jarak tanam. Jarak tanam yang digunakan pada penelitian ini tidak menghasilkan adanya persaingan unsur hara yang dibutuhkan oleh tanaman.

Tabel 1. Pengaruh kombinasi jarak tanam dengan PPC terhadap biomassa tanaman total tanaman hanjeli pada 16 minggu setelah tanam.

\begin{tabular}{|c|c|c|c|c|c|c|c|}
\hline \multicolumn{2}{|c|}{ Perlakuan } & \multirow{2}{*}{$\begin{array}{l}\text { Tinggi } \\
\text { tanaman } \\
(\mathrm{cm})\end{array}$} & \multirow{2}{*}{$\begin{array}{l}\text { Jumlah } \\
\text { daun per } \\
\text { tanaman }\end{array}$} & \multirow{2}{*}{$\begin{array}{l}\text { Jumlah } \\
\text { anakan per } \\
\text { rumpun }\end{array}$} & \multirow{2}{*}{$\begin{array}{l}\text { Jumlah } \\
\text { srisip }\end{array}$} & \multirow{2}{*}{$\begin{array}{l}\text { Indeks } \\
\text { Luas Daun } \\
\text { (ILD) }\end{array}$} & \multirow{2}{*}{$\begin{array}{c}\text { Nisbah } \\
\text { pupus akar }\end{array}$} \\
\hline $\begin{array}{l}\text { Jarak tanam } \\
(\mathrm{cm})\end{array}$ & PPC & & & & & & \\
\hline \multirow[t]{3}{*}{$50 \times 50$} & $2 \mathrm{ml} / 1$ & 255,00 a & 54,67 a & 13,67 a & 96,67 a & $4,71 \mathrm{~b}$ & $4,04 \mathrm{a}$ \\
\hline & $4 \mathrm{ml} / 1$ & 250,33 a & 54,67 a & 13,67 a & $77,00 \mathrm{a}$ & $4,80 \mathrm{~b}$ & $1,73 \mathrm{a}$ \\
\hline & $6 \mathrm{ml} / 1$ & 247,92 a & 56,67 a & 14,17 a & $114,33 \mathrm{a}$ & $4,93 \mathrm{~b}$ & 3,37 a \\
\hline \multirow[t]{3}{*}{$75 \times 50$} & $2 \mathrm{ml} / 1$ & 224,83 a & $57,00 \mathrm{a}$ & $14,25 \mathrm{a}$ & $82,67 \mathrm{a}$ & $3,34 \mathrm{a}$ & 3,17 a \\
\hline & $4 \mathrm{ml} / 1$ & 240,75 a & 47,67 a & $11,92 \mathrm{a}$ & $64,00 \mathrm{a}$ & $2,60 \mathrm{a}$ & $2,45 \mathrm{a}$ \\
\hline & $6 \mathrm{ml} / 1$ & 251,83 a & 52,67 a & 13,17 a & $102,33 \mathrm{a}$ & $3,00 \mathrm{a}$ & 3,15 a \\
\hline \multirow[t]{3}{*}{$100 \times 50$} & $2 \mathrm{ml} / 1$ & 229,50 a & $43,00 \mathrm{a}$ & $10,75 \mathrm{a}$ & $120,67 \mathrm{a}$ & $1,72 \mathrm{a}$ & 3,15 a \\
\hline & $4 \mathrm{ml} / 1$ & $252,00 \mathrm{a}$ & $66,67 \mathrm{a}$ & $16,67 \mathrm{a}$ & $110,33 \mathrm{a}$ & $2,71 \mathrm{a}$ & $2,94 \mathrm{a}$ \\
\hline & $6 \mathrm{ml} / 1$ & 249,50 a & 65,33 a & $16,33 \mathrm{a}$ & $45,67 \mathrm{a}$ & $2,86 \mathrm{a}$ & $2,54 \mathrm{a}$ \\
\hline
\end{tabular}

Keterangan : Nilai rata-rata yang diikuti dengan huruf yang sama pada kolom yang sama tidak berbeda nyata menurut uji Scott-Knott pada taraf $5 \%$.

Pengaruh pengaturan jarak tanam dan pemberian PPC terhadap jumlah daun tanaman hanjeli juga menunjukkan hasil yang tidak berbeda nyata (Tabel 1). Hal ini diduga karena unsur hara $\mathrm{N}$ dan $\mathrm{P}$ cukup tersedia dan curah hujan yang cukup tinggi pada awal fase pertumbuhan, sehingga kebutuhan semua tanaman tercukupi dan membuat jumlah anakan yang dihasilkan relatif sama. Pembentukan daun oleh tanaman sangat dipengaruhi oleh ketersedian unsur hara nitrogen dan fosfor pada medium yang tersedia bagi tanaman. Kedua unsur ini berperan dalam pembentukan selsel baru dan komponen utama penyusun senyawa organik dalam tanaman seperti asam amino, asam nukleat, klorofil, ADP dan ATP. Pemberian nitrogen dalam jumlah banyak akan menyebabkan pertumbuhan vegetatif yang lebat dan warna daun menjadi tua.

Hasil analisis ragam terhadap jumlah anakan per rumpun juga menunjukkan tidak ada perbedaan yang nyata antar perlakuan. Meskipun tidak berbeda nyata, namun jumlah anakan hanjeli pada percobaan ini mencapai 16,67 anakan dan cukup baik bila dibandingkan pada deskripsi tanaman hanjeli aksesi 37 dimana anakan hanya mencapai 10,22. Pembentukan anakan dipengaruhi oleh kandungan unsur hara nitrogen, fosfor, kalium dan besi. Apabila kandungan unsur hara tersebut rendah maka akan menghasilkan produksi anakan yang rendah pula. Kandungan unsur hara tembaga yang optimum akan meningkatkan produksi anakan. Unsur hara $\mathrm{N}$ cukup di dalam tanah maka tanaman dapat menghasilkan anakan yang optimal, meskipun demikian jumlah anakan yang tumbuh tersebut tidak semuanya menghasilkan malai (Barbieri et al., 2000).

Srisip merupakan kumpulan dari malai utama yang muncul pada ketiak daun tanaman hanjeli. Jumlah srisip tanaman hanjeli relatif seragam yaitu 5,3 - 11,2 srisip pada setiap anakan (Tabel 1). Pembentukan srisip dipengaruhi oleh unsur nitrogen, fosfor dan kalium. Tidak berpengaruhnya perlakuan kombinasi jarak tanam dengan PPC pada jumlah srisip antar perlakuan diduga karena curah hujan yang cukup dan unsur hara yang tercukupi pada awal fase pertumbuhan, sehingga kebutuhan semua tanaman tercukupi dan menghasilkan jumlah srisip yang relatif sama. Bila dibandingkan dengan deskripsi hanjeli aksesi 37 yang memiliki jumlah srisip 3,12 per tanaman, perlakuan kombinasi jarak tanam dengan PPC menghasilkan jumlah srisip yang lebih baik karena mencapai 11,2 srisip per tanaman.

Hasil analisis menunjukkan bahwa terdapat pengaruh nyata pengaturan jarak tanam dan pemberian PPC terhadap indeks luas daun (ILD) 
tanaman hanjeli pada umur 16 MST. Perlakuan jarak tanam 50 x $50 \mathrm{~cm}$ dikombinasikan dengan konsentrasi PPC $2 \mathrm{ml} / \mathrm{l}, 4 \mathrm{ml} / \mathrm{l}$ atau $6 \mathrm{ml} / \mathrm{l}$ berbeda nyata dengan perlakuan lainnya. Nilai ILD tertinggi terdapat pada perlakuan jarak tanam 50 x $50 \mathrm{~cm}$ dikombinasikan dengan konsentrasi PPC $2 \mathrm{ml} / \mathrm{l}$ dengan nilai 4,93 namun tidak berbeda nyata dengan perlakuan jarak tanam 50 x $50 \mathrm{~cm}$ dikombinasikan dengan konsentrasi PPC $2 \mathrm{ml} / \mathrm{l}$ atau $4 \mathrm{ml} / \mathrm{l}$. ILD merupakan parameter yang menunjukan potensi tanaman melakukan fotosintesis dan potensi produktif tanaman di lapangan. Luas daun yang lebih besar akan menyerap lebih banyak cahaya matahari sehingga proses fotosintesis dalam tumbuhan tersebut optimal dan menghasilkan fotosintat yang digunakan untuk membentuk berbagai jaringan tanaman dimana jaringan tanaman yang berkembang dengan baik akan diikuti dengan penambahan bobot tanaman dan bobot kering tanaman. Perbedaan besarnya ILD disebabkan oleh perbedaan kerapatan tanaman dan penyediaan hara terutama nitrogen yang sangat mempengaruhi besarnya luas daun (Capriyati dkk., 2014; Wahyudin dkk., 2016).

Produksi dan perluasan daun yang cepat sangat penting pada produksi tanaman budidaya agar dapat memaksimalkan penyerapan cahaya dan asimilasi. Indeks luas daun juga dipengaruhi oleh besarnya evapotranspirasi yang terjadi selama pertumbuhan tanaman. Besarnya evapotranspirasi berbanding terbalik dengan besarnya ILD (Loveless, 1991). Air juga merupkan salah satu faktor penting bagi pertumbuhann tanaman yang berperan dalam perluasan atau pembesaran sel sehingga memperbesar luas daun.

Tabel 1 menunjukan bahwa tidak terdapat pengaruh antara perlakuan kombinasi jarak tanam dengan pemberian PPC terhadap nisbah pupus akar (NPA). Hal ini diduga karena kurangnya pasokan unsur hara yang berperan dalam pembentukan akar tanaman. Berdasarkan analisis kimia tanah awal, tanah yang digunakan selama percobaan meemiliki kandungan $\mathrm{P}$ dalam tanah tergolong rendah. Nisbah pupus akar yang ideal bagi tanaman pangan adalah 3 (Salisbury \& Ross, 1995). Nilai nisbah pupus akar pada percobaan kali ini berkisar antara 1,73 - 4,04. Nilai NPA rendah menunjukkan bahwa pertumbuhan tanaman terarah pada pembentukan akar. Sebaliknya, bila nilainya lebih tinggi maka hal tersebut menunjukkan bahwa pertumbuhan tanaman terarah pada pembentukan pupus. Nilai bobot kering akar yang rendah dapat menggambarkan bahwa akar berada dalam kondisi kurang optimal untuk penyerapan air dan unsur hara. Semakin besar bobot kering akar, menggambarkan akar berada dalam kondisi yang semakin optimal dalam penyerapan air dan unsur hara.

\section{Komponen Hasil}

Hasil analisis statistik menunjukkan bahwa tidak ada pengaruh nyata kombinasi jarak tanam dengan PPC terhadap jumlah malai per rumpun. Hal ini disebabkan karena anakan yang terbentuk tidak seluruhnya memproduksi malai. Produksi malai pada tanaman hanjeli dipengaruhi oleh beberapa faktor, dimana yang paling utama adalah ketersediaan unsur hara. Menurut Budi (1998) kemampuan tanaman dalam menghassilkan malai ditentukan oleh banyaknya anakan serta faktor status air tanah selama masa vegetatif. Peluang malai yang dapat dihasilkan akan semakin besar bila jumlah anakan lebih dari satu benih relatif banyak. Ketersediaan air yang cukup pada seluruh fase tumbuh tanaman membuat pertumbuhan tunas relatif sama yang juga membuat proses timbulnya malai relatif sama. Seragamnya jumlah malai juga karena kandungan unsur makro dan mikro yang di perlukan dalam pembentukan malai sudah terpenuhi. Kekurangan unsur $\mathrm{Ca}, \mathrm{Fe}, \mathrm{Mg}$ dan $\mathrm{Zn}$ dapat menyebabkan malai yang terbentuk sedikit. Sedangkan kekurangan unsur Mn dapat menyebabkan malai muda mati (Salisbury \& Ross, 1995).

Berdasarkan hasil analisis ragam pada Tabel 2 menunjukkan bahwa perlakuan kombinasi jarak tanam dengan PPC tidak memberikan pengaruh terhadap jumlah biji per rumpun dan jumlah biji per petak. Hasil biji lebih banyak ditentukan oleh kondisi optimum dari fase pertumbuhan seperti periode pembungaan, pengisian biji, pematangan dan pemasakan. Proses tersebut berhubungan dengan total luas daun pada fase pembungaan yang dapat berpengaruh terhadap ketersediaan fotosintat pada malai (Maddoni et al., 2006). Nilai kekerasan biji didapatkan dengan menggunakan alat penetrometer dengan cara menekan alat pada biji sampai biji pecah, kemudian didapatkan nilai sesuai pada angka yang tertera pada jarum penetrometer. Tabel 2 menunjukkan bahwa nilai kekerasan biji terbesar adalah pada perlakuan B yaitu kombinasi jarak tanam 50 x 50 dengan penambahan PPC 4 ml/1 dengan nilai 17,56. 
Tabel 2. Pengaruh kombinasi jarak tanam dengan PPC terhadap jumlah biji per rumpun dan per petak.

\begin{tabular}{|c|c|c|c|c|c|}
\hline \multicolumn{2}{|c|}{ Perlakuan } & \multirow{2}{*}{$\begin{array}{l}\text { Jumlah Malai } \\
\text { per Rumpun }\end{array}$} & \multirow{2}{*}{$\begin{array}{c}\text { Jumlah Biji per } \\
\text { Rumpun }\end{array}$} & \multirow{2}{*}{$\begin{array}{c}\text { Jumlah Biji per } \\
\text { Petak }\end{array}$} & \multirow{2}{*}{ Kekerasan biji } \\
\hline Jarak tanam $(\mathrm{cm})$ & PPC & & & & \\
\hline \multirow[t]{3}{*}{$50 \times 50$} & $2 \mathrm{ml} / 1$ & $215,00 \mathrm{a}$ & 1064,82 a & 4770,42 a & 12,9 \\
\hline & $4 \mathrm{ml} / 1$ & $265,00 \mathrm{a}$ & $918,28 \mathrm{a}$ & $4330,21 \mathrm{a}$ & 17,6 \\
\hline & $6 \mathrm{ml} / 1$ & 177,67 a & 1073,38 a & $3961,21 \mathrm{a}$ & 13,4 \\
\hline \multirow[t]{3}{*}{$75 \times 50$} & $2 \mathrm{ml} / 1$ & $287,00 \mathrm{a}$ & 1649,89 a & 3850,36 a & 12,8 \\
\hline & $4 \mathrm{ml} / 1$ & $253,00 \mathrm{a}$ & 2003,97 a & 4314,38 a & 13,8 \\
\hline & $6 \mathrm{ml} / 1$ & 336,33 a & $1848,51 \mathrm{a}$ & 4189,53 a & 15,5 \\
\hline \multirow[t]{3}{*}{$100 \times 50$} & $2 \mathrm{ml} / 1$ & 252,33 a & 1039,23 a & 2265,69 a & 15,6 \\
\hline & $4 \mathrm{ml} / 1$ & $265,00 \mathrm{a}$ & $1998,81 \mathrm{a}$ & 3851,82 a & 13,8 \\
\hline & $6 \mathrm{ml} / 1$ & $460,00 \mathrm{a}$ & $1498,95 \mathrm{a}$ & $3321,58 \mathrm{a}$ & 13,9 \\
\hline
\end{tabular}

Keterangan : Nilai rata-rata yang diikuti dengan huruf yang sama pada kolom yang sama tidak berbeda nyata menurut uji Scott-Knott pada taraf $5 \%$.

\section{Hasil Hanjeli}

Pengaruh perlakuan jarak tanam dan pemberian PPC terhadap komponen hasil hanjeli ditampilkan pada Tabel 3. Dapat dilihat bahwa tidak terdapat pengaruh yang nyata antara perlakuan kombinasi jarak tanam dengan PPC terhadap bobot 100 biji, bobot biji per rumpun, bobot biji per petak dan bobot 100 biji. Hal ini diduga karena kebutuhan tanaman atas unsur-unsur yang mempengaruhi bertambahnya bobot biji sudah tercukupi selama pemupukan awal serta pupuk susulan. Tabel 3 menunjukan bobot 100 butir dapat mencapai 15,33 g dan cukup baik bila dibandingkan dengan deskripsi hanjeli aksesi 37 dimana bobot 100 butir hanya mencapai 12,92 g.

Tabel 3. Pengaruh kombinasi jarak tanam dengan ppc terhadap bobot 100 butir, bobot biji per rumpun, bobot biji per petak, bobot biji per ha, rendemen biji pecah kulit, dan indeks panen.

\begin{tabular}{|c|c|c|c|c|c|c|c|}
\hline \multicolumn{2}{|c|}{ Perlakuan } & \multirow[b]{2}{*}{$\begin{array}{l}\text { Bobot } 100 \\
\text { butir (gr) }\end{array}$} & \multirow{2}{*}{$\begin{array}{l}\text { Bobot Biji } \\
\text { per } \\
\text { Rumpun } \\
\text { (gr) }\end{array}$} & \multirow[b]{2}{*}{$\begin{array}{l}\text { Bobot Biji } \\
\text { per Petak } \\
\quad(\mathrm{gr})\end{array}$} & \multirow[b]{2}{*}{$\begin{array}{l}\text { Bobot biji } \\
\text { /ha (ton) }\end{array}$} & \multirow[b]{2}{*}{$\begin{array}{c}\text { Rendemen } \\
\text { Biji Pecah } \\
\text { Kulit }\end{array}$} & \multirow[b]{2}{*}{$\begin{array}{l}\text { Indeks } \\
\text { Panen }\end{array}$} \\
\hline $\begin{array}{l}\text { Jarak tanam } \\
(\mathrm{cm})\end{array}$ & PPC & & & & & & \\
\hline \multirow[t]{3}{*}{$50 \times 50$} & $2 \mathrm{ml} / 1$ & $14,00 \mathrm{a}$ & $149,08 \mathrm{a}$ & $4770,42 \mathrm{a}$ & 5,96 & $67,40 \mathrm{c}$ & $0,25 \mathrm{~b}$ \\
\hline & $4 \mathrm{ml} / 1$ & $15,33 \mathrm{a}$ & 135,32 a & $4330,21 \mathrm{a}$ & 5,41 & $59,17 \mathrm{~b}$ & $0,06 \mathrm{a}$ \\
\hline & $6 \mathrm{ml} / 1$ & $12,00 \mathrm{a}$ & 123,79 a & $3961,21 \mathrm{a}$ & 4,95 & $73,80 \mathrm{c}$ & 0,06 a \\
\hline \multirow[t]{3}{*}{$75 \times 50$} & $2 \mathrm{ml} / 1$ & $11,67 \mathrm{a}$ & $192,52 \mathrm{a}$ & 3850,36 a & 5,13 & $76,67 \mathrm{c}$ & $0,12 \mathrm{a}$ \\
\hline & $4 \mathrm{ml} / 1$ & $11,00 \mathrm{a}$ & $215,72 \mathrm{a}$ & $4314,38 \mathrm{a}$ & 5,75 & $56,34 \mathrm{~b}$ & $0,14 \mathrm{a}$ \\
\hline & $6 \mathrm{ml} / 1$ & $11,33 \mathrm{a}$ & 209,48 a & $4189,53 \mathrm{a}$ & 5,58 & $69,93 \mathrm{c}$ & $0,14 \mathrm{a}$ \\
\hline \multirow[t]{3}{*}{$100 \times 50$} & $2 \mathrm{ml} / 1$ & $14,00 \mathrm{a}$ & $141,61 \mathrm{a}$ & $2265,69 \mathrm{a}$ & 2,83 & $49,80 \mathrm{a}$ & $0,10 \mathrm{a}$ \\
\hline & $4 \mathrm{ml} / 1$ & $12,00 \mathrm{a}$ & 240,74 a & $3851,82 \mathrm{a}$ & 4,82 & $72,47 \mathrm{c}$ & $0,16 \mathrm{a}$ \\
\hline & $6 \mathrm{ml} / 1$ & $14,00 \mathrm{a}$ & 207,60 a & $3321,58 \mathrm{a}$ & 4,15 & $70,07 \mathrm{c}$ & $0,09 \mathrm{a}$ \\
\hline
\end{tabular}

Keterangan : Nilai rata-rata yang diikuti dengan huruf yang sama pada kolom yang sama tidak berbeda nyata menurut uji Scott-Knott pada taraf $5 \%$.

Menurut Marsiwi dkk. (2015) dan Hidayat dkk. (2015) unsur fosfor merupakan bahan untuk pembentukan protein dalam biji, sedangkan unsur $\mathrm{K}$ berperan dalam bertambahnya bobot biji. Peranan K adalah membuat tanaman menjadi lebih berisi dan lebih padat. Menurut Parnata (2004), kekurangan unsur hara $\mathrm{Cl}$ akan menyebabkan produksi tanaman rendah dan kekurangan Mn dapat mengakibatkan pembentukan biji kurang baik. Bobot biji tidak dipengaruhi oleh jarak tanam dan dosis pupuk, namun disebakan oleh volume lemma dan palea pada biji yang ditentukan oleh faktor genetik tanaman itu sendiri. Menurut Mayadewi (2007), unsur hara makro dan mikro yang terkandung dalam pupuk pelengkap cair dengan dosis yang cukup untuk memenuhi kebutuhan hara pada daun untuk berfotosintesis secara optimal. Tingkat fotosintesis yang tinggi karena intensitas cahaya yang optimum pada pertanaman yang ditunjang oleh ketersediaan air yang mencukupi akan menghasilkan asimilat 
yang cukup untuk pengisian biji, yang pada akhirnya akan memberikan kontribusi pada bobot 100 butir.

Hasil analisis sidik raagam menunjukkan bahwa perlakuan kombinasi jarak tanam dengan PPC memberikan pengaruh nyata terhadap rendemen pecah kulit (Tabel 3) menunjukan adanya perbedaan nyata pada parameter rendemen pecah kulit. Hasil tertinggi terdapat pada perlakuan kombinasi jarak tanam 75 x $50 \mathrm{~cm}$ dengan konsentrasi PPC 2 ml/l dengan nilai sebesar 76,67 dimana memberikan pengaruh terbaik di bandingkan perlakuan jarak tanam 50 x $50 \mathrm{~cm}$ dengan konsentrasi PPC $4 \mathrm{ml} / \mathrm{l}$, jarak tanam 75 x 50 $\mathrm{cm}$ dengan konsentrasi PPC $4 \mathrm{ml} / \mathrm{l}$, dan jarak tanam 100 x $50 \mathrm{~cm}$ dengan konsentrasi PPC 2 ml/1 namun tidak berbeda nyata dengan perlakuan lainnya. Hal ini disebabkan karena fotosintat rendah yang menyebabkan pengisian biji menjadi berkurang dan bobot kulit pelindung biji hanjeli tidak seragam. Ada tiga faktor penting selama proses pengisian biji, yaitu produksi fotosintat yang dihasilkan oleh organ tanaman yang berfungsi sebagai source, sistem translokasi dari source ke sink, dan akumulasi fotosintat pada sink. Hasil tertinggi terdapat pada perlakuan $\mathrm{D}$, yaitu perlakuan kombinasi jarak tanam 75 x $50 \mathrm{~cm}$ dengan aplikasi PPC $2 \mathrm{ml} / 1$ dengan nilai sebesar $76,67 \%$.

Kombinasi jarak tanam dengan PPC memberikan pengaruh berbeda nyata terhadap indeks panen (IP). Perlakuan A yaitu kombinasi jarak tanam $75 \times 50 \mathrm{~cm}$ dengan aplikasi PPC $2 \mathrm{ml} / 1$ memiliki indeks panen yang berbeda nyata dengan nilai tertinggi yaitu sebesar 0,25. Nilai indeks panen merupakan besarnya translokasi asimilat dari tempat pemupukannya di pelepah daun dan pangkal batang ke bulir. Nilai IP yang tinggi menunjukkan bahwa tanaman tersebut efisien karena hasil fotosintesisnya dapat ditranslokasikan ke organ yang akan di panen. Menurut Kastomo (2005), besarnya indeks panen ditentukan dan dipengaruhi oleh pertumbuhan dan perkembangan organ tanaman, baik organ vegetatif maupun generatif, nilai indeks luas daun dapat digunakan sebagai tolak ukur produktivitas tanaman.

\section{SIMPULAN}

Kombinasi jarak tanam dengan aplikasi PPC memberikan pengaruh terhadap indeks luas daun, rendemen pecah kulit, dan indeks panen. Kombinasi jarak tanam 50 x $50 \mathrm{~cm}$ dengan konsentrasi PPC $2 \mathrm{ml} / \mathrm{l}$ memberikan pengaruh terbaik terhadap hasil tanaman hanjeli yaitu bobot biji per petak sebesar 4,77 kg per petak dan bobot biji per hektar sebesar 5,96 ton per hektar. Perlakuan jarak tanam dan pupuk pelengkap cair sangat berpengaruh terhadap hasil tanaman hanjeli.

\section{DAFTAR PUSTAKA}

Barbieri, PA, HRS Rozas, FH Andrade and $\mathrm{HE}$ Echeverria. 2000. Soil management; row spacing effect at different levels of nitrogen availability in maize. Agronomy Journal. 92: 283-288.

Capriyati, R, Tohari, dan D Kastono. 2014. Pengaruh jarak tanam dalam tumpangsari Sorgum manis (Sorghum bicolor L. Moench) dan dua habitus Wijen (Sesamum indicum L.) terhadap pertumbuhan dan hasil. Vegetalika. 3 (3): 49-62.

Hidayat, AM, E Ambarwati, S Wedhastri, dan P Basunanda. 2015. Pengujian lima pupuk organik cair komersial dan pupuk NPK pada Jagung (Zea mays L.). Vegetalika. 4 (4): 920.

Grubben, GJH, and S Partohardjono. 1996. Plant Resources of South-East Asia No 10 Cereals. Blackhuys Publisher. Leiden Netherlands.

Irwan, AW, ÃT Nurmala, dan TD Nira. 2017. Pengaruh jarak tanam berbeda dan berbagai dosis pupuk kandang ayam terhadap pertumbuhan dan hasil tanaman hanjeli pulut (Coix lacryma-jobi L.) di dataran tinggi Punclut. Jurnal Kultivasi 16 (1): 233245.

Kastomo, D. 2005. Tanggapan pertumbuhan dan hasil kedelai hitam terhadap penggunaan pupuk organik dan biopestisida gulma siam (Chromolaena odorata). Ilmu Pertanian. 12 (2): $103-116$.

Maddoni, GA, AG Cirilo and ME Otegui. 2006. Row width and maize grain yield. Agronomy Journal. 98: 1532-1543.

Marsiwi, T, S Purwanti, dan D Prajitno. 2015. Pengaruh jarak tanam dan takaran pupuk NPK terhadap pertumbuhan dan hasil benih kacang hijau (Vigna radiata L. Wilczek). Vegetalika. 4 (2): 124-132.

Mayadewi, NNA. 2007. Pengaruh jenis pupuk kandang dan jarak tanam terhadap pertumbuhan gulma dan hasil jagung manis. Agritrop. 26 (4): 153-159.

Nurmala, T, dan AW Irwan. 2007. Pangan Alternatif Berbasis Serealia Minor. Penerbit Giratuna. Bandung. 
Pederson, P, and JG Laurer. 2003. Corn and soybean response to rotation sequence, row spacing and tillage system. Agronomy Journal. 95: 965-971.

Putra. S. 2011. Pengaruh jarak tanam terhadap peningkatan hasil padi gogo varietas Situ Patenggang. Agrin. 15(1): 54-63.

Puspadewi, S, W Sutari, dan Kusumiyati. 2016. Pengaruh konsentrasi pupuk organic cair (POC) dan dosis pupuk N, P, K terhadap pertumbuhan dan hasil tanaman jagung manis (Zea mays L.var Rugosa Bonaf) kultivar Talenta. Jurnal Kultivasi. 15(3): 208-216.

Rahmayani. 2006. Efektivitas Pupuk Pelengkap Cair Dharmavit Terhadap Pertumbuhan, Produksi, Serta Serapan Hara N, P, K Tanaman Padi Sawah (Oryza sativa L.) Varietas IR 64 pada Latosol Darmaga. Institut Pertanian Bogor. Bogor.
Ruminta dan T Nurmala. 2016. Dampak perubahan pola curah hujan terhadap tanaman pangan lahan tadah hujan di jawa barat. Agrin. 20(2): 155-168.

Ruminta, A Wahyudin, dan S Sakinah. 2017. Respon pertumbuhan dan hasil tanaman padi terhadap jarak tanam pada lahan tadah hujan dengan menggunakan pengairan intermittent. Agrin. 21(1): 46-58.

Salisbury, FB dan CW Ross. 1995. Fisiologi Tumbuhan. ITB Press. Bandung.

Wahyudin, A, Ruminta, dan DC Bachtiar. 2015. Pengaruh jarak tanam berbeda pada berbagai dosis pupuk organik terhadap pertumbuhan dan hasil jagung hibrida $\mathrm{P}-12$ di Jatinangor. Jurnal Kultivasi 14 (1): 1- 8.

Wicaksono, F, Y Yustiana, dan A Supriatna. 2006. Pengembangan plasma nutfah hanjeli (Coix lacryma-jobi L.) sebagai pangan potensial berbasis tepung di kawasan Punclut kabupaten Bandung. PKMK-2-4-1. 